\title{
Genotypic Variation among Okra (Abelmoschus esculentus (L.) Moench) Germplasms in South India
}

\author{
Kishor Doddanakatte Shivaramegowda ${ }^{1}$, Arya Krishnan ${ }^{2}$, Yogeesh Kebbahalli Jayaramu ${ }^{3}$, Vinod Kumar ${ }^{4}$, Yashoda ${ }^{4}$, \\ Hee-Jong $\mathrm{Koh}^{1} *$ \\ ${ }^{1}$ Department of Plant Science, College of Agriculture \& Life Sciences, Seoul National University 08826, Korea \\ ${ }^{2}$ Department of Plant Breeding and Genetics, College of Agriculture, Kerala Agricultural University, Vellayani, Trivandrum 695522, \\ India \\ ${ }^{3}$ Department of Farm Engineering, Banaras Hindu University, Varanasi 221005, India \\ ${ }^{4}$ International Crops Research Institute for Semi-Arid Tropics (ICRISAT), Patancheru, Hyderabad 502324, India
}

\begin{abstract}
Thirty-six okra germplasms were grown and evaluated for yield and yield related traits at the Department of Plant Breeding and Genetics, Vellayani, Trivandrum, Kerala. The germplasms studied possessed sufficient variability for all the traits. High genotypic coefficient of variation (GCV) and phenotypic coefficient of variation (PCV) were noticed for almost all characters and narrow difference between GCV and PCV suggest that environmental influence is minimal for the traits studied. High estimates of heritability coupled with high to moderate genetic advance as percent over mean was recorded for all the characters considered. Yield had positive and significant association with number of fruits per plant, fruit weight, fruit girth and number of primary branches indicating that selection based on these characters may improve yield. Principal component analysis indicated that first three principal components contributed for sixty percent total variation among ten characters describing accessions. The cluster analysis revealed that hybridization of cluster I with cluster IV would be beneficial to develop promising varieties under diverse climatic conditions in India.
\end{abstract}

Keywords Genotypic variation, Okra germplasms, Principal component analysis, Cluster analysis

\section{INTRODUCTION}

Okra (Abelmoschus esculentus (L.) Moench) also known as lady's finger, Bhindi and gumbo belonging to the family Malvaceae. According to De Candolle (1886), West African considered to be the origin of Okra due to distribution of related wild species in the Nile Valley and Ethiopia. However, Bates (1968), reported that Okra originated in South and South-East Asia as wild relatives are abundantly distributed in the region. Chheda and Fatokun (1982) reported the existence of records which indicated that okra was cultivated in Egypt prior to 1216 A.D. The studies by Martin et al. (1981) distinguished two major classes of okra, the conventional and unconventional types, as earlier described by Siemonsma (1980; 1982). Siemonsma (1982) and Singh and Bhatnagar (1975) reported that the West African okra contained 194 chromosomes as against 130 of the conventional okra, thus constituting a new okra species.

Okra is an important vegetable crop mainly grown for its tender, delicious green fruits which are cooked, canned and consumed in various forms. Nutritionally, it's rich in carbohydrate, fat, fibers, oil, mineral, and vitamins viz., B1, A, and C (Rashwan 2011). The leaves are sometimes used as cattle feed. Fresh okra fruit contains $2.1 \mathrm{~g}$ protein, $0.2 \mathrm{~g}$ fat, $8 \mathrm{~g}$ carbohydrate, 36 calories, $1.7 \mathrm{~g}$ fiber, 175.2 $\mathrm{mg}$ minerals, and $88 \mathrm{ml}$ of water per $100 \mathrm{~g}$ of edible portion (Tindall, 1983; Berry et al., 1988). Its edible leaf per $100 \mathrm{~g}$ contains about $81 \mathrm{ml}$ water, 56 calories, $11 \mathrm{~g}$ carbohydrate and $4.4 \mathrm{~g}$ protein. Industrially, mucilage of Okra has been added as size to gaze certain paper used confectionary. The stem is almost large with bark and fibers which are suitable

Received May 3, 2016; Revised May 26, 2016; Accepted May 26, 2016; Published May 31, 2016

*Corresponding author Hee-Jong Koh, heejkoh@snu.ac.kr, Tel: +82-2-880-4541, Fax: +82-2-873-2056 
for spinning into rope and for paper and card board manufacturing (Chevalier 1940; Charrier 1984). The fibers are used to make fishing lines, game traps and sponges (Osawaru and Dania-Ogbe 2010). Okra is widely distributed and cultivated in tropics and subtropics of the world. India is one the leading okra producer with the production of 6.346 million t year $^{-1}$ from an area of 0.532 million ha, with the productivity of $11.9 \mathrm{t} \mathrm{ha}^{-1}$ (National Horticulture Board 2014).

The reduction in the productivity and yield in okra is mainly due to lack of location specific varieties tolerant to pests and diseases such as fruit and shoot borer and yellow vein mosaic virus disease (Thirupathi Reddy et al. 2012). Hence, the first step in okra improvement should involve evaluation of the germplasm to assess the existing genetic variability for yield and yield related traits. The knowledge on nature and magnitude of variation existing in available breeding materials would help in choosing characters for effective selection of potential parents for further use in breeding programme. A better understanding of the extent of genetic diversity among okra germplasms is necessary for planning selection programme aimed at improvement of yield. Realizing the importance of developing high yielding okra genotypes, the present study was undertaken to assess the variability and genetic diversity of okra germplasms for various agro-morphological traits under peninsular conditions of Southern India.

\section{MATERIALS AND METHODS}

The field experiments were carried out in the Department of Plant Breeding and Genetics, College of Agriculture, Vellayani, Trivandrum during 2011 to 2012. The material for the study comprised of 36 accessions of okra collected from different geographical regions of India. The details of the germplasms used in the present study are given in Table 1. Crop management practices were followed as per the recommendation of Kerala Agricultural University (2007).

\section{Data collection and analysis}

All the 36 germplasms were sown at a spacing of $60 \times 45$ $\mathrm{cm}$ in a randomized block design with three replication in a plot size of $3.6 \mathrm{~m}^{2}$. Five competitive plants per treatment in each replication were selected randomly and tagged. Observations were recorded on these plants for different traits viz., Days to first flowering, number of fruits per plant, leaf axil bearing first fruit, fruit weight (g), number of primary branches, fruit length $(\mathrm{cm})$, plant height $(\mathrm{cm})$, fruit girth $(\mathrm{cm})$, crop duration (days), yield per plant (g) and the

Table 1. List of germplasms of okra used for evaluation.

\begin{tabular}{ccc}
\hline \hline Accession & Local names of & Place of collection \\
No. & collected germplasms & \\
\hline AE-1 & IC 7119 & NBPGR, New Delhi \\
AE-2 & IC 1012-1 & NBPGR, New Delhi \\
AE-3 & Hosalli Local & Koratagere, Karnataka \\
AE-4 & Punjab Phalgani & NBPGR, New Delhi \\
AE-5 & HRB-9-2 & UAS (Bangalore) \\
AE-6 & AE-201 & Vellanikkara, Kerala \\
AE-7 & Mara Bhendi & Khalaghatagi, Karnataka \\
AE-8 & Thirumala Local & Trivandrum, Kerala \\
AE-9 & Belagavi Local & Belagavi, Karnataka \\
AE-10 & Mandya Local & Mandya, Karnataka \\
AE-11 & Neyyar Local & Trivandrum, Kerala \\
AE-12 & Poovam Local & Panniyur, Kerala \\
AE-13 & Kattakada Local & Trivandrum, Kerala \\
AE-14 & Krishnarajapet Local & Krishnarajapet, Karnataka \\
AE-15 & Kalliyur Local & Vellayani, Kerala \\
AE-16 & Nagamangala Local & Nagamangala, Karnataka \\
AE-17 & Nedumangad Local & Trivandrum, Kerala \\
AE-18 & PHS 9394 & UAS (Bangalore) \\
AE-19 & Cherthala Local & Alleppey, Kerala \\
AE-20 & Varsha Upahar & Vellayani, Kerala \\
AE-21 & Mysore Local & Mysore, Karnataka \\
AE-22 & Azhoor Local & Pathanamthitta, Kerala \\
AE-23 & Neeleshwaram Local & Kasargod, Kerala \\
AE-24 & Bhendi 070 & Belagavi, Karnataka \\
AE-25 & Karunagapally Local & Quilon, Kerala \\
AE-26 & Arka Anamika & IIHR, Bangalore \\
AE-27 & AE-102 & Vellanikkara, Kerala \\
AE-28 & Halu Bhendi & KVK, Brammavara \\
AE-29 & AE-116 & Vellanikkara, Kerala \\
AE-30 & Arka Abhay & IIHR, Bangalore \\
AE-31 & IC 140910 & NBPGR, New Delhi \\
AE-32 & Kunnapuzha Local & Trivandrum, Kerala \\
AE-33 & Holavanahalli Local & Koratagere, Karnataka \\
AE-34 & Mallapalli Local & Kottayam, Kerala \\
AE-35 & Tirur Local & Malapuram, Kerala \\
\hline AE-36 & Vadakkumcheri Local & Palakad, Kerala \\
\hline
\end{tabular}


mean of five plants for each germplasm per replication were subjected to ANOVA (Panse and Sukhatme 1985) to examine the presence of statistically significant differences among accessions for the characters measured. Genotypic and phenotypic analysis coefficient of variation were performed as per formula suggested by Burton (1952). Heritability and genetic advance were calculated by using the formula given by Lush (1937) and Allard (1960). Heritability $>80 \%$ considered as high (Robert et al. 2009). Genotypic and phenotypic correlation coefficients were calculated using SPAR 2.0 (http://iasri.res.in/spar/.) based on the respective variances and co-variances of the characters which showed significant variation in the ANOVA. And finally, based on correlation matrix and similarity matrix, multivariate analysis like principal component analysis (PCA), and cluster analysis were performed on Genstat 13.1 release (2010; VSN International, Hemel Hempstead, UK).

\section{RESULTS}

\section{Mean performance and genetic variability}

The 36 germplasms differed significantly (Table 2) for all the characters studied. The range and mean for all the characters presented in Table 3 . The mean values for days to first flowering ranged from 36.33 to 46.53 ; leaf axil bearing first fruit ranged from 4.13 to 6.73 ; number of primary branches ranged from 1.00 to 4.26 ; crop duration ranged from 80.26 to 128.06 days. Wide variation was observed for plant height from 45.73 to $138.40 \mathrm{~cm}$. Fruit related traits differed significantly among the germplasms.

Table 2. Analysis of variance for various characters of okra germplasms.

\begin{tabular}{lccc}
\hline \hline \multirow{1}{*}{ Character } & \multicolumn{3}{c}{ Mean sum of square } \\
\cline { 2 - 4 } & Replication & Germplasms & Error \\
\hline Days to first flowering & 0.21 & $31.49^{* *}$ & 0.59 \\
Leaf axil bearing first fruit & 0.07 & $2.13^{* *}$ & 0.04 \\
Number of primary branches & 0.01 & $1.96^{* *}$ & 0.01 \\
Plant height (cm) & 15.64 & $1813.57^{* *}$ & 9.31 \\
Crop duration (d) & 2.55 & $507.34^{* *}$ & 1.39 \\
Number of fruits per plant & 0.3 & $25.96^{* *}$ & 0.29 \\
Fruit weight (g) & 0.3 & $15.61^{* *}$ & 0.18 \\
Fruit length (cm) & 0.18 & $4.56^{* *}$ & 0.1 \\
Fruit girth (cm) & 0.006 & $0.50^{* *}$ & 0.03 \\
Yield per plant (g) & 230.38 & $13412.09^{* *}$ & 104.19 \\
\hline
\end{tabular}

**Indicates significant at 0.01 probability level.

Table 3. Estimates of variability parameters for various characters of okra germplasms.

\begin{tabular}{lccrrrr}
\hline \multicolumn{1}{c}{ Characters } & Mean & Range & PCV & GCV & $h^{2}$ & GA as $\%$ mean \\
\hline Days to first flowering & 41 & $36.33-46.53$ & 8.04 & 7.82 & 94.58 & 15.67 \\
Leaf axil bearing first fruit & 5.24 & $4.13-6.73$ & 16.41 & 15.88 & 93.24 & 31.65 \\
Number of primary branches & 2.08 & $1.00-4.26$ & 40.43 & 39.95 & 97.61 & 81.3 \\
Plant height (cm) & 96.73 & $45.73-138.40$ & 25.54 & 25.35 & 98.47 & 51.82 \\
Crop duration (d) & 95.94 & $80.26-128.06$ & 13.59 & 13.53 & 99.17 & 27.76 \\
Number of fruits per plant & 16.1 & $10.13-23.26$ & 18.46 & 18.15 & 96.69 & 36.78 \\
Fruit weight (g) & 14.26 & $9.60-20.86$ & 16.18 & 15.9 & 96.56 & 32.19 \\
Fruit length (cm) & 13.09 & $9.23-16.09$ & 9.64 & 9.3 & 93.08 & 18.51 \\
Fruit girth (cm) & 6.46 & $5.32-7.36$ & 6.72 & 6.11 & 82.59 & 11.44 \\
Yield per plant (g) & 231.27 & $127.96-482.93$ & 29.13 & 28.79 & 97.71 & 58.63 \\
\hline
\end{tabular}

\footnotetext{
${ }^{\text {z) }} \mathrm{PCV}$ : phenotypic coefficient of variation, GCV: genotypic coefficient of variation, $\mathrm{h}^{2}$ : heritability, GA: genetic advance.
} 
Number of fruits per plant ranged from 10.13 to 23.26 , fruit weight was from 9.60 to $20.86 \mathrm{~g}$, fruit length ranged from 9.23 to $16.09 \mathrm{~cm}$ and fruit girth ranged from 5.32 to 7.36 $\mathrm{cm}$. High range of variation was observed for yield per plant ranging from 127.96 to $482.92 \mathrm{~g}$.

In the variability studies (Table 3 ), phenotypic coefficient of variation (PCV) was higher than genotypic coefficient of variation (GCV) for all the characters with close correspondence between them. This indicated the fact that environmental influence was very low and hence selection for these characters would be made based on their phenotypic performance. Moderate and high GCV values for most of the characters except days to first flowering, fruit length and fruit girth revealed the presence of high magnitude of genetic variability in the population studied. Among the ten characters studied, seven characters displayed high heritability (low $<30 \%$, moderate $31 \%$ to $60 \%$ and high $>60 \%$ ) coupled with high genetic advance (low $<10 \%$, moderate $11 \%$ to $20 \%$ and high $>20 \%$ ) as percent over mean. This emphasizes the predominance of additive gene effects for these characters and crop improvement through selection based on these characters would be feasible. Three characters, such as., days to first flowering, fruit length, and fruit girth showed high heritability accompanied with moderate genetic advance over mean implying the role of non-additive effects and hence selection based on these traits may not be rewarding.

\section{Comelation analysis}

The Pearson correlation coefficient has been presented in Table 4 . The crop duration was highly significantly correlated with plant height ( $\mathrm{r}=0.57$ at $P=0.01$ ) and days to first flowering ( $\mathrm{r}=0.28$ at $P=0.28$ ). The number of fruits per plant had positive significant correlation with number of primary branches $(\mathrm{r}=0.36$ at $P=0.01)$ and vice- versa. Selection of germplasm with more primary branches leads to correlated selection for more number of fruits per plant in Okra. Increase in primary branches results in increases the number of fruits. The association between fruit weight was linearly correlated with number of fruits per plant at $P=0.05$ with correlation value of $r=0.25$. There was positive significant correlation among fruit length and fruit weight ( $\mathrm{r}=0.48$ at $P=0.01$ ). This signifies that increase in Okra fruit length result in increase in fruit weight. Fruit girth had significant correlation with number of fruits per plant $(\mathrm{r}=0.39)$ and fruit weight $(\mathrm{r}=0.38)$ at $P=0.01$. The yield per plant had strong significant correlation with number of fruits per plant $(\mathrm{r}=0.79)$ and fruit weight $(\mathrm{r}=0.78)$, fruit girth $(\mathrm{r}=0.46)$ and number of primary branches $(\mathrm{r}=0.35)$ at $P=0.01$. Number of fruits per plant, fruit weight, fruit girth and number of primary branches were important traits for selecting high yielding germplasm in Okra.

\section{Principal component Analysis}

PCA (Table 5, Fig. 1) was performed in order to provide

Table 4. Correlation studies in okra germplasms.

\begin{tabular}{lcccccccccc} 
& DFF $^{\mathrm{z}}$ & LBFF & NPB & PH $(\mathrm{cm})$ & DR $(\mathrm{d})$ & NFPP & FW $(\mathrm{g})$ & FL $(\mathrm{cm})$ & FG $(\mathrm{cm})$ & YPP $(\mathrm{g})$ \\
\hline DFF & 1 & 0.07 & -0.01 & 0.03 & $-0.28^{*}$ & 0.08 & 0.17 & 0.19 & -0.14 & 0.17 \\
LBFF & 0.07 & 1 & 0.01 & 0.13 & $-0.25^{*}$ & -0.008 & -0.10 & -0.12 & -0.16 & -0.05 \\
NPB & -0.01 & 0.01 & 1 & -0.02 & -0.08 & $0.36^{* *}$ & 0.19 & -0.04 & 0.17 & $0.35^{* *}$ \\
PH (cm) & 0.03 & 0.13 & -0.02 & 1 & $0.57 * *$ & 0.07 & 0.05 & -0.21 & -0.11 & 0.07 \\
DR (d) & $-0.28^{*}$ & $-0.25^{*}$ & -0.08 & $0.57 * *$ & 1 & -0.08 & 0.08 & -0.11 & 0.07 & -0.0006 \\
NFPP & 0.08 & -0.008 & $0.36^{* *}$ & 0.07 & -0.08 & 1 & $0.25^{*}$ & -0.09 & $0.39 * *$ & $0.79 * *$ \\
FW (g) & 0.17 & -0.10 & 0.19 & 0.05 & 0.08 & $0.25^{*}$ & 1 & $0.43^{* *}$ & $0.38^{* *}$ & $0.78^{* *}$ \\
FL (cm) & 0.19 & -0.12 & -0.04 & -0.21 & -0.11 & -0.09 & $0.43^{* *}$ & 1 & 0.09 & 0.19 \\
FG (cm) & -0.14 & -0.16 & 0.17 & -0.11 & 0.07 & $0.39 * *$ & $0.38^{* *}$ & 0.09 & 1 & $0.46^{* *}$ \\
YPP (g) & 0.17 & -0.05 & $0.35^{* *}$ & 0.07 & -0.0006 & $0.79 * *$ & $0.78^{* *}$ & 0.19 & $0.46^{* *}$ & 1 \\
\hline
\end{tabular}

${ }^{z)} \mathrm{DFF}$ : days to first flowering, LBFF: leaf axil bearing first fruit, NPB: number of primary branches, PH: plant height, DR: crop duration, NFPP: number of fruits per plant, FW: fruit weight, FL: fruit length, FG: fruit girth, YPP: yield per plant. *, ** indicates significant at 0.05 and at 0.01 probability level respectively. 
Table 5. Principal component scores for various okra germplasms.

\begin{tabular}{lrrr}
\hline \hline \multicolumn{1}{c}{ Character } & PCA I & PCA II & PCA III \\
\hline Days to first flowering & 0.104 & -0.323 & 0.045 \\
Leaf axil bearing first fruit & -0.083 & -0.127 & 0.505 \\
Number of primary branches & 0.277 & 0.011 & 0.350 \\
Plant height (cm) & -0.003 & 0.566 & 0.102 \\
Crop duration (d) & -0.012 & 0.658 & -0.284 \\
Number of fruits per plant & 0.442 & 0.084 & 0.375 \\
Fruit weight (g) & 0.467 & -0.012 & -0.289 \\
Fruit length (cm) & 0.177 & -0.327 & -0.534 \\
Fruit girth (cm) & 0.370 & 0.089 & -0.109 \\
Yield per plant (g) & 0.567 & 0.040 & 0.072 \\
\hline
\end{tabular}

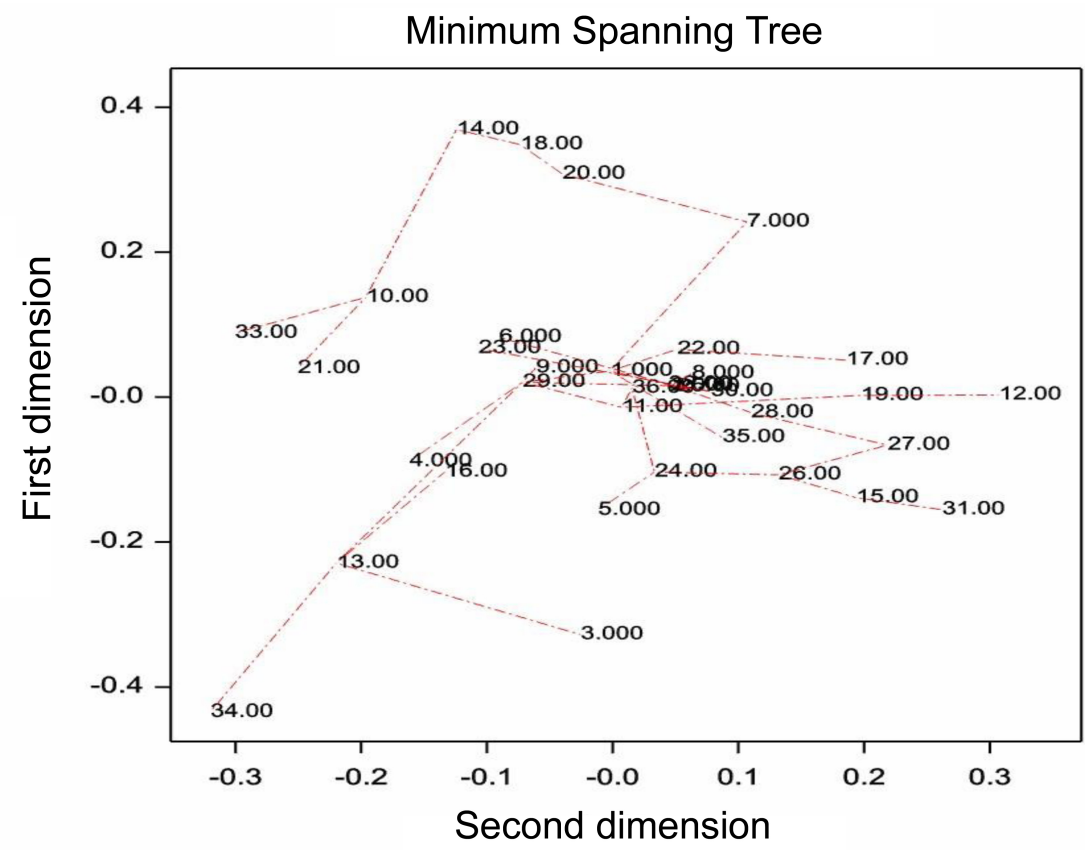

Fig. 1. Two dimensional representation of principal component analysis plot.

partial visualization of the data set in reduced dimension and first three principal components contributed for $59.77 \%$ variation. From the loading of the variables it was found that yield per plant, fruit weight and number of fruits per plant were the dominant features which contributed for $28.37 \%$ of total variation. In PCA II, crop duration and plant height exerted maximum influence which accounts for $17.42 \%$ of total variation. However, Leaf axil bearing first fruit, number of fruits per plant and number of primary branches per plant were the dominant features in PCA III which accounted for $13.98 \%$ of total variation.

\section{Cluster analysis}

The hierarchical cluster analysis among 36 germplasm for yield and yield related traits using coefficient of Euclidean complete linked similarity index resulted in four different clusters (Fig. 2). The clustering was not based on similar geographical origin. Cluster I found to be largest as it accommodated 12 germplasms. The cluster II comprised of 8 germplasms. The cluster III found to be the smallest among the four clusters and it comprised of 6 germplasms. The cluster IV comprised of 10 germplasms. 


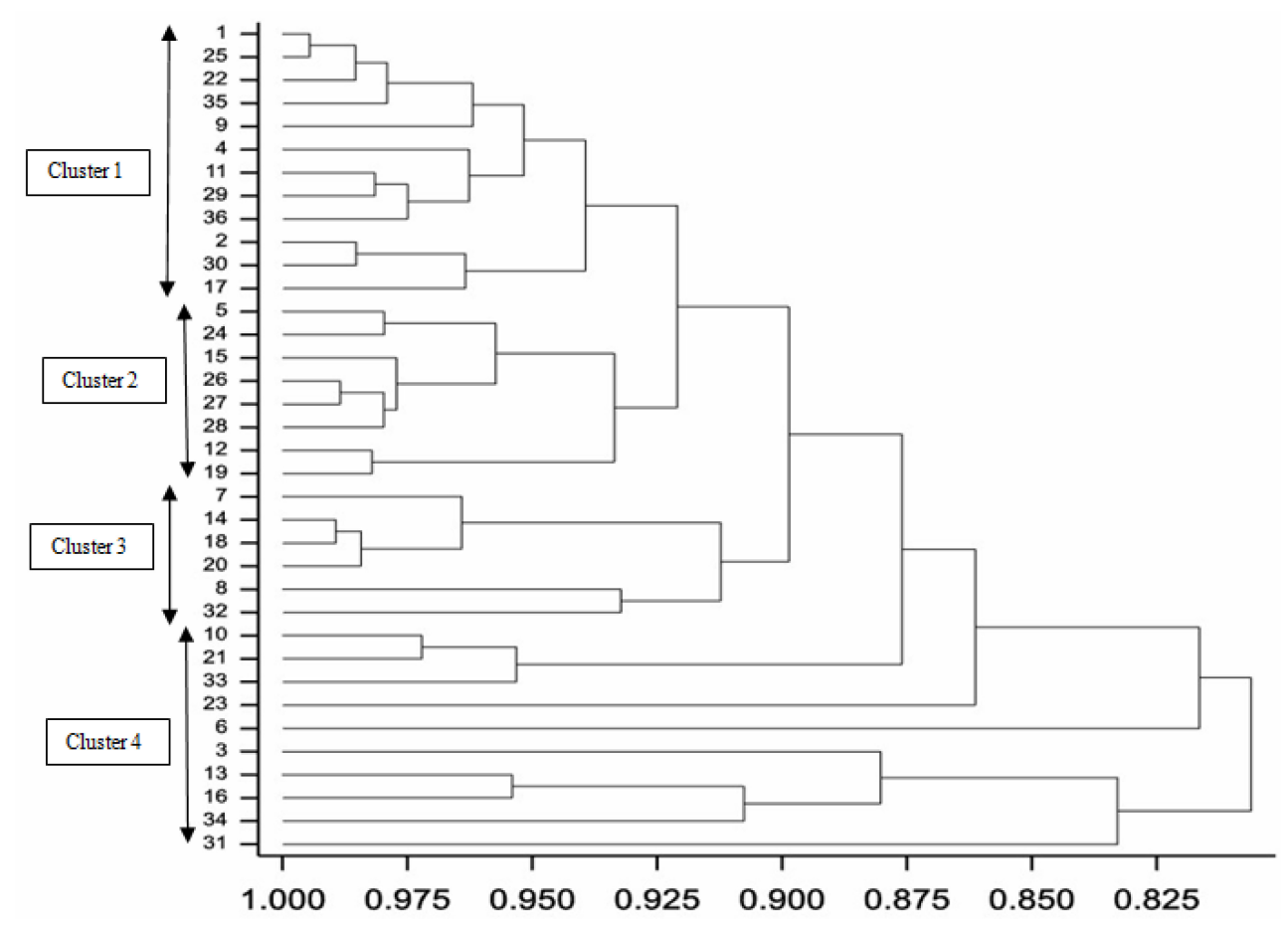

Fig. 2. Dendrogram showing genetic relationship among 36 Okra germplasms based on quantitative traits using coefficient of euclidean complete linked similarity index.

\section{DISCUSSION}

The Okra germplasms exhibited sizeable variation for all the characters. Among thirty six germplasms studied, few germplasms were found to flower earlier in 37 days, which may be exploited in breeding programme to produce early types. Similar results were reported by Rajani and Manju (1997). Sixteen germplasms had more branches than the general mean and twenty germplasms had fewer branches than general mean (2.08). The leaf axil bearing first fruit found to be have exhibited good amount of variation and Eighteen germplasms have recorded plant height less than mean value $96.73 \mathrm{~cm}$ and remaining germplasms have been found to be tall. The crop duration also exhibited commendable variation. The above findings were supported by Rajani and Manju (1997), and Duggi et al. (2013). Considerable amount of variation was noticed for fruit characters viz., number of fruits per plant, fruit weight, fruit length, and fruit girth and corroborative findings were reported by Akotkar et al. (2010) and Duggi et al. (2013). The yield per plant showed remarkable high variation in the present study and it was also supported by Akotkar et al. (2010) and Duggi et al. (2013).

Greater magnitude of PCV and GCV was observed for yield per plant and its component characters like number of primary branches and plant height. These findings are in agreement with Thirupathi Reddy et al. (2012) and Duggi et al. (2013). Moderate PCV and GCV were observed for number of fruits per plant, leaf axil bearing first fruit, fruit weight, and crop duration and corroborative findings were reported by Rajani and Manju (1997) and Mulge et al. (2004). In the present study, the days to first flowering, fruit length and fruit girth recorded low PCV and GCV values. This indicates the presence of narrow genetic base for these traits. This is in conformity with the findings of Dhankar and Dhankar (2002) and Akotkar et al. (2010).

High heritability for days to first flowering and number of primary branches in the present investigation is in accordance with the reports of Thirupathi Reddy et al. (2012). High heritability estimated for plant height, fruit yield and its related characters like number of fruits per plant, fruit weight, fruit length, and fruit girth in the present 
study is well in agreement with the reports of Thirupathi Reddy et al. (2012) and Duggi et al. (2013). High estimates of genetic advance as percentage of mean were recorded for number of primary branches, number of fruits per plant, plant height, crop duration (days), leaf axil bearing first fruit, fruit weight and yield per plant. Several research findings are in line with this result such as Akotkar et al. (2010), Thirupathi Reddy et al. (2012) and Duggi et al. (2013).

Yield had positive association with number of fruits per plant, fruit weight, fruit girth and number of primary branches in the present study is well in agreement with reports by Sindhumole et al. (2006) and Adiger et al. (2011). The significant positive correlation of fruit yield per plant with number of fruits per plant, fruit weight, fruit girth and number of primary branches indicates that selection for these characters would lead to simultaneous improvement for yield per plant in okra.

PCA indicated high genetic diversity among the okra germplasm is in accordance with the report of Sharma and Prasad (2010). The cluster analysis revealed that cluster I represents germplasms from diverse geographical regions of India. Cluster I comprised of early crop duration germplasms which has collected from malapuram and very popular land races with stand against biotic and abiotic stresses as it has been adapted to local climatic condition. This cluster also included of dwarf germplasm. The cluster II comprised of early crop duration germplasm which has been collected Vellayani, Kerala. Cluster III comprised of germplasms having high fruit length which has been collected from Thiruvanantapuram, Kerala. The cluster III comprised of germplasms having high number of primary branches, high fruit girth, higher number of fruits per plant, high fruit weight, early flowering types, and high fruit yield per plant. The last cluster assumes greater significance in breeding programme as it accommodated most of the desirable which breeder looks for developing new hybrid or variety. Crossing programme involving genetically diverse lines has been effective for the development of novel hybrids with high rate of heterosis in the desired direction (Mallikarjun et al. 2010). As cluster IV has highest value for fruit weight (g), yield per plant are an important yield related trait, therefore hybridization of cluster I with cluster IV would be beneficial with the advantage that cluster I leading local varieties and check varieties performing excellent in under diverse climatic conditions of India.

From this study, it also evident that yield and its related traits offer immense scope for improvement through selection based on their high magnitude of heritability and genetic advance. The significant positive correlation of fruit yield per plant with number of fruits per plant, fruit weight, fruit girth and number of primary branches indicates that selection for these characters would lead to simultaneous improvement for yield per plant. This study also confirmed that presence of genetic diversity for further use in improvement program.

\section{ACKNOWLEDGEMENTS}

This study was supported by Department of Plant Breeding and Genetics, College of Agriculture, Vellayani, Trivandrum funded by Kerala Agricultural University. The authors are highly grateful to the Department of Plant Breeding and Genetics, College of Agriculture, Vellayani, Trivandrum, Kerala for providing all necessary materials to carry out the present study.

\section{REFERENCES}

Adiger S, Shanthkumar G, Gangashetty PI, Salimath PM. 2011. Association studies in okra (Abelmoschus esculentus (L.) Moench). Electr J. Plant Breed. 2: 568-573.

Akotkar PK, De DK, Pal AK. 2010. Genetic variability and diversity in okra (Abelmoschus esculentus (L.) Moench). Electr. J. Plant Breed. 1: 393-398.

Allard RW. 1960. Principles of plant breeding. John Wiley and Sons, New York, NY. p.485.

Bates DM. 1968. Notes on the cultivated Malvaceae 2. Abelmoschus Baileya 16: 99-112.

Berry SK, Kalra CL, Schyal RC. 1988. Quality characteristics of seeds of five okra (A. esculentus [L.] Moench) cultivars. J. Food Sci. Tech. 25: 303.

Burton GW. 1952. Quantitative inheritance in grasses. Proc. of the 6th International Grassland Congress Pennsylvania 
State College. State College, PA. 1: 277-283.

Charrier A. 1984. Genetic resources of the genus Abelmoschus Med. (Okra). IBPGR, Rome, Italy. p.61.

Chevalier A. 1940. L'origin, la culture et les usage de cinq Hibiscus de la section Abelmoschus. Rev. Bot. Appl. Agric. Trop. 20: 319-328.

Chheda HR, Fatokun CA. 1982. Numerical analysis of variation patterns in okra (Abelmoschus esculentus L. Moench). Bot. Gaz. 143: 253-261.

De Candolle A. 1886. Origin of cultivated plants. Hather, New York, NY.

Dhankar BS, Dhankar SK. 2002. Variability studies in okra (Abelmoschus esculentus (L.) Moench). Haryana J. Hort. Sci. 31: 82-84.

Duggi S, Magadum S, Srinvasraghavan A, Kishor DS, Oommen SK. 2013. Genetic analysis of yield and yieldattributing characters in okra (Abelmoschus esculentus (L.) Moench.). Int. J. Agric. Env. Biotech. 6: 45-50.

Kerala Agricultural University. 2007. Package of practices recommendations: crops. 13th ed. KAU, Thrissur, p.161-162.

Lush JL. 1937. Animal breeding plans. Iowa State College Press, Ames, IA.

Mallikarjun D, Allolli TB, Hulihalli UK, Athani SI. 2010. Genetic diversity studies in kharif onion (Allium cepa var. cepa L.). Karnataka J. Agric. Sci. 23: 811-812.

Martin FW, Rhodes AM, Perez M, Diaz F. 1981. Variation in okra. Euphytica 30: 697-715.

Mulge R, Jaiprakashnarayan RP, Madalageri MB. 2004. Studies on genetic variability for fruit and yield parameters in okra (Abelmoschus esculentus (L.) Moench). Karnataka J. Hort. 1: 1-5.

National Horticulture Board (NHB). 2014. Indian horticulture database 2014. NHB, Gurgaon, India.

Osawaru ME, Dania-Ogbe FM. 2010. Ethnobotanical revelations and traditional uses of West African, okra $[A$. caillei (A. Chev.) Stevels] among tribes in Sough Western Nigeria. Plant Arch. 10: 211-217.

Panse VG, Sukhatme PV. 1985. Statistical methods for Agricultural workers. 4th ed. Indian council of Agricultural Research, New Delhi, India. p.63-69.

Panse VG. 1957. Genetics of quantitative characters in relation to plant breeding. Indian J. Genet. Pl. Br. 17:
318-328.

Rajani B, Manju P. 1997. Variability studies in okra (Abelmoschus esculentus L. Moench.). South Indian J. Hort. 45: 61-62.

Rashwan AMA. 2011. Study of genotypic and phenotypic correlation for some agro-economic traits in okra (Abelmoschus esculentus (L.) Moench). Asian J. Crop. Sci. 3: 85-91.

Robert RR, Meyer WA, Bonos SA. 2009. Classification and inheritance of morphological and agronomic characteristics in Kentucky Bluegrass (Poa pratensis L.). Hort. Sci. 44: 274-279.

Sharma RK, Prasad K. 2010. Classification of promising okra (Abelmoschus esculentus) genotypes based on principal component analysis. J. Trop. Agric. Fd. Sc. 38: 161-169.

Siemonsma JS. 1980. Bilan des etudes conduites sur le gombo. Rapport Annual, 1979-1980. Centre Neerlandais, Abidjan, I. Coast. 35: 38.

Siemonsma JS. 1982. West African okra-morphological and cytogenetical indications for the existence of a natural amphidiploid of Abelmoschus Esculentus L. Moench and A. manihot L. Medikus. Euphytica 31: 241-242.

Sindhumole P, Manju P, Vijayaraghavakumar. 2006. Genetic parameters of selected yield attributes in okra (Abelmoschus esculentus (L.) Moench). Madras Agric. J. 93: 262-266.

Singh HB, Bhatnagar A. 1975. Chromosome number in an okra from Ghana. Indian J. Genet. Plant Breed. 36: 24-27.

SPAR 2.0: Statistical Package for Agricultural Research Ver. 2.0 [Internet]. Indian Agricultural Statistics Research Institute, New Delhi, India. [cited 2016 May 2]. Available from: http://iasri.res.in/spar.

Thirupathi Reddy M, Hari Babu K, Ganesh M, Chandrasekhar reddy K, Begum $\mathrm{H}$, Purushothama Reddy B, et al. 2012. Genetic variability analysis for the selection of elite genotypes based on pod yield and quality from the germplasm of okra (Abelmoschus esculentus L. Moench). J. Agric. Technol. 8: 639-655.

Tindall HD. 1983. Vegetables in the tropics. Macmillian Press Ltd., London and Basingstoke. p.325-328.

VSN International, Hemel Hempstead, UK. 2010. Available from: http:/www.vsni.co.uk/software/genstat/. 